\title{
PENINGKATAN DAYA SAING USAHA MUKENA DAN KESET KAKI DI KECAMATAN PERCUT SEI TUAN
}

\author{
Khairunnisa Harahap ${ }^{1 *}$, Dita Amanah ${ }^{2}$ \\ ${ }^{1}$ Fakultas Ekonomi, Universitas Negeri Medan, Medan, Indonesia \\ *Penulis Korespondensi: nisaharahap77@gmail.com
}

\begin{abstract}
Abstrak
Tujuan kegiatan IbM ini adalah untuk meningkatkan daya saing usaha UPPKS Mukena dan keset kaki di kecamatan Percut Sei Tuan. Berdasarkan survey dan analisis situasi yang dilakukan maka dapat diidentifikasi permasalahan sebagai berikut : 1) Belum terorganisasinya pembukuan dengan baik. 2) pemasaran produk masih sangat seerhana belum menggunakan peran teknologi. Permasalahan yang paling utama bagi kelompok usaha ini adalah belum adanya produk mukena bordir yang beragam, sehingga kurang sesuai dengan permintaan pasar. Sedangkan untuk produk keset kaki, di perlukan gambar karakter keset kasi yang beragam serta ukuran produk yang berbeda pula sehingga hargany adapat bervariasi. Berdasarkan permasalahan yang dihadapi mitra maka solusi yang ditawarkan UPPKS Mukena dan Keset Kaki adalah pelatihan dan pendampingan dalam membuat diversifikasi produk dan differensiasi produk sehingga dapat meningkatkan daya saing dan menaikkan omzet penjualan. Pelatihan dalam pembukuan dilakukan dengan memberikan pemahaman terkait dengan pencatatan kas masuk dan keluar, penghitungan harga pokok produksi dan pembuatan laporan keuangan. Pelatihan dalam pemasaran yaitu pemasaran yang melibatkan teknologi sehingga proses pemasaran bisa intensif dan juga masif. Metode yang dipakai dalam IbM ini adalah dengan menggunakan pelatihan dan pendampingan terkait dengan pembukuan dan pemasaran serta pembuatan produk yang bernilai ekonomi tinggi.
\end{abstract}

Kata Kunci : Daya Saing, IbM, Pendampingan, Pelatihan, Pembukuan, Pemasaran

\begin{abstract}
The purpose of this IbM activity is to improve business competitiveness of UPPKS Mukena and doormat foot in Percut Sei Tuan district. Based on survey and situation analysis that can be identified problem as follows: 1) Not well organized bookkeeping. 2) product marketing is still very simple yet use the role of technology. The most important problem for this business group is the absence of various embroidery mukena products, so it is less in line with market demand. As for the product of the foot mat, in need of drawing character of mats are different and the size of different products so that hargany adapat vary. Based on the problems faced by partners, the solutions offered by UPPKS Mukena and Keset Kaki are training and assistance in making product diversification and product differentiation in order to increase competitiveness and increase sales turnover. Training in bookkeeping is done by providing an understanding related to the recording of cash in and out, calculation of cost of goods production and preparation of financial statements. Training in marketing is marketing that involves technology so that the marketing process can be intensive and also massive. The method used in IbM is by using training and assistance related to bookkeeping and marketing and manufacturing of high value economic products.
\end{abstract}

Keywords: Competitiveness, IbM, Assistance, Training, Bookkeeping, Marketing

\section{PENDAHULUAN}

\subsection{Analisis Situasi}

Kelompok usaha industi rumahan kerajinan adalah entitas usaha yang menghasilkan produk-produk yang sangat bergantung pada keahlian tenaga pengrajin yang tersedia. Usaha industri rumahan ini terbukti memberikan kontribusi yang positif terhadap peningkatan penghasilan keluarga.

Dua mitra yang terlibat dalam IbM Peningkatan Daya Saing Usaha Produk Mukena dan Keset kaki adalah 2 kelompok usaha industry rumahan yang terletak di Desa Sambirejo Kecamatan Percut Sei Tuan. Mitra pertama yaitu Ibu Suprianti menjalankan usaha industry "Bordir dan Keset Kaki" yang dirintisnya sejak tahun 2005, hingga saat ini sudah mempunyai 10 orang karyawan yang terdiri dari ibu-ibu rumah tangga dan remaja wanita putus sekolah. Usaha ini merupakan industry rumahan (Home Industry) yang memproduksi Mukena diperuntukan untuk wanita dewasa serta anak-anak, Mukena yang diproduksi sudah di pasarkan ke seluruh daerah di Sumatera 
Utara dan provinsi lain di Indonesia seperti: Nusa Tenggara Timur, Kudus, Bangka Belitung, Jambi dan DKI Jakarta. Hal ini membuktikan bahwa mukena yang dihasilkan sangat diminati oleh berbagai kalangan masyarakat di Indonesia.

Dalam system pemasarannya usaha ini telah mengikuti berbagai macam pameran yang diselenggarakan baik di tingkat regional maupun di tingkat nasional. Namun system pemasaran yang dilakukan tidak langsung ke konsumen melainkan di pasarkan ke agen-agen atau reseller setelah itu baru dipasarkan ke konsumen, dimana usaha ini akan menerima pesanan dari agen atau reseller dan setelah pesanan itu datang barulah kegiatan produksi dilakukan. Usaha industry "Bordir dan Keset Kaki" yang ditekuni Ibu Suprianti masih menggunakan manajemen usaha sederhana yang berlandaskan azas kekeluargaan dan belum mengadopsi sistem manajemen modern. Disamping itu, walaupun dilakukan pembukuan dan pencatatan keuangan, namun pembukuan yang dilakukan tidak relevan sebagai bahan acuan dalam pengambilan keputusan dan tidak bisa dipertanggung jawabkan dikarenakan pembukuan dilakukan oleh orang yang berbeda-beda setiap harinya. Oleh karena hal tersebut sulit mendapatkan pinjaman modal dari pihak perbankan meskipun telah beberapa kali mencoba mengajukan pinjaman kredit.
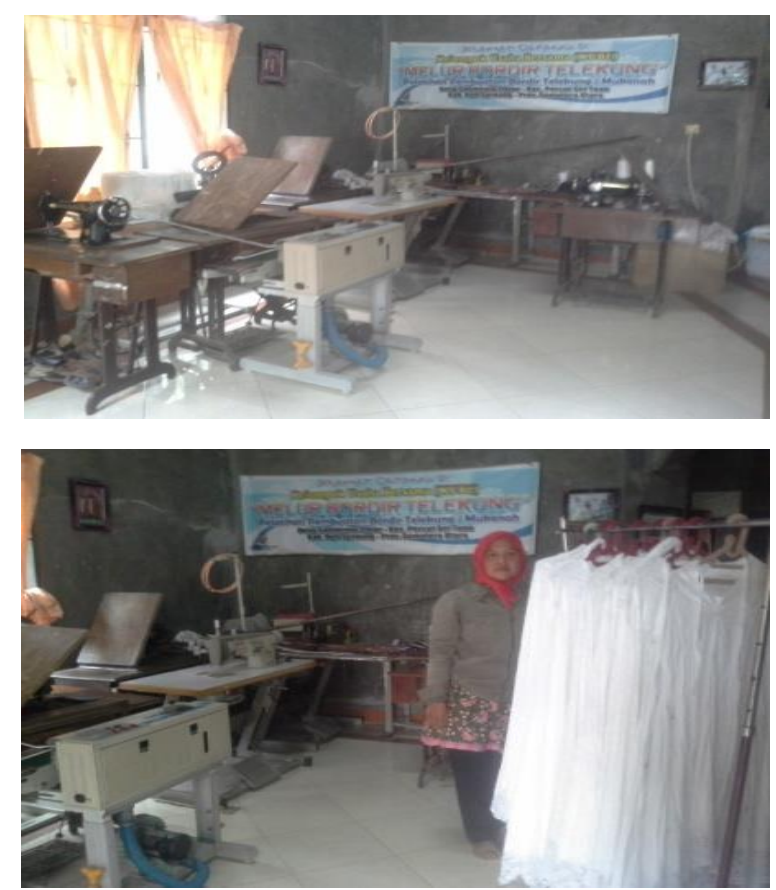

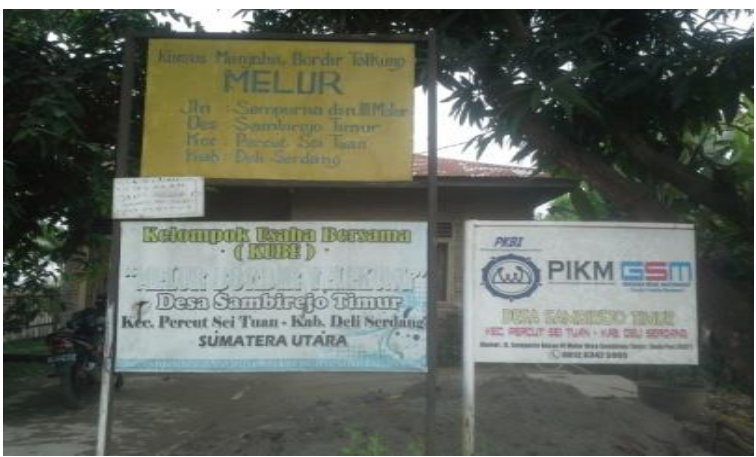

Gambar 1.1. Lokasi Usaha Mitra 1 Bordir Melur

Sementara Mitra kedua yang menjalankan usaha kerajinan tangan Keset Kaki diketuai oleh Ibu Dwi Agustina yang memulai usaha setahun yang lalu tepatnya tahun 2015. Walaupun usahanya terbilang masih "seumur jagung" namun, sampai saat ini telah memiliki 3 orang anngota yang mayoritas berprofesi sebagai ibu-ibu rumah tangga. Usaha yang dijalankan juga merupakan industry rumahan (Home Industry) yang memproduksi Keset Kaki. Produk yang dihasilkan tersebut telah di pasarkan ke daerah Medan dan sekitarnya, Keset Kaki tersebut terbukti cukup diminati oleh masyarakat terbukti dengan permintaan pasar yang semakin meningkat dari tahun sebelumnya. Namun disamping itu, usaha industry rumahan ini masih menggunakan manajemen usaha yang masih sangat sederhana, hal ini dibuktikan dengan tidak adanya pencatatan keuangan dan pembukuan dalam kegiatan operasional usahanya serta quality control yang tidak dilakukan terhadap produk yang dihasilkan. Dengan karyawan yang merupakan ibu-ibu rumah tangga dimana kemampuan seni yang didapat merupakan hasil otodidak sehingga mengakibatkan desain produk yang dihasilkan masih sederhana.
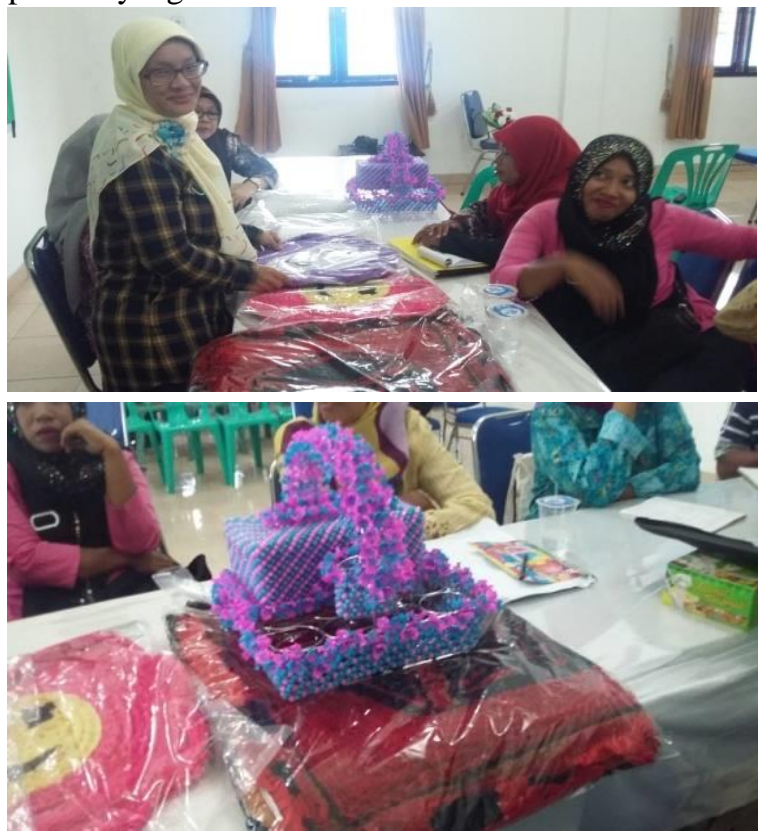

Gambar 1.2. Produk Mitra 2 Lestari 
Hubungan Mitra I dan ke II adalah terkait dengan kesamaan produk keset kaki dari mitra I dan Mitra ke II. Mereka menggunakan bahan jeans bekas untuk untuk pemanfaatan limbah, dikarenakan jarak lokasi produksi antara mitra I dengan mitra II relatif sangat berdekatan, maka mitra I dan II cukup sering saling meminjam alat seperti mesin jahit, yang menjadi kendala utama bagi mitra kedua khususnya ketika sedang menerima orderan keset kaki dalam jumlah yang lebih besar dari pihak reseller. Di sisi lain, terkadang hal tersebut menjadi kendala tersendiri bagi kedua mitra yang dapat menghambat proses produksi produk yang dihasilkan oleh mereka ketergantungan terhadap peralatan mesin jahit. Selain itu, kedua mitra tersebut sebenarnya sudah pernah memperoleh bantuan mesin jahit dari pemerintah. Tetapi karena kendala mesin jahit yang sering rusak, mesin yang tidak sesuai dengan kebutuhan sehingga menjadi hambatan terbesar dalam menjalankan proses produksi. Pembukuan yang tidak rapi menjadi salah satu kendala susahnya mendapat modal kerja. Pemasaran yang belum luas juga menjadi kendala yang sulit di pecahkan.

\subsection{Permasalahan Mitra}

Tabel 2.1 Permasalahan Kunci pada Mitra IbM

\begin{tabular}{|c|c|}
\hline $\begin{array}{l}\text { Usaha Industry } \\
\text { "Bordir Melur" } \\
\text { Mukena }\end{array}$ & $\begin{array}{l}\text { Usaha Industry Keset Kaki } \\
\text { "Lestari" }\end{array}$ \\
\hline 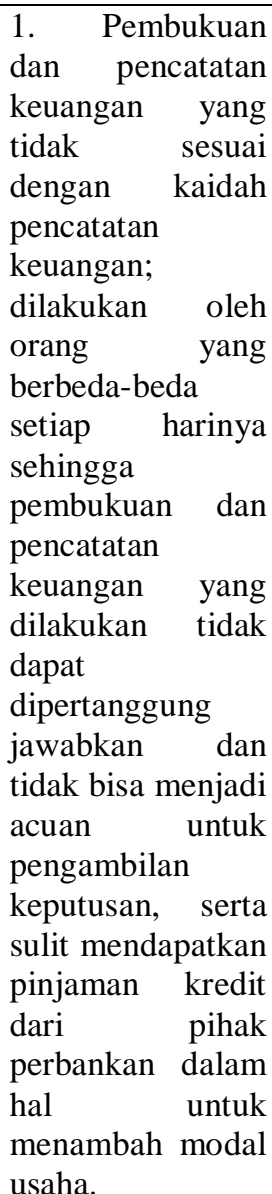 & $\begin{array}{l}\text { 1. Tidak dilakukan } \\
\text { Pembukuan dan pencatatan } \\
\text { keuangan dalam tingkat yang } \\
\text { paling sederhana misalnya } \\
\text { pencatatan arus kas masuk } \\
\text { (cash inflow) maupun arus kas } \\
\text { keluar (cash outflow). Hal ini } \\
\text { disebabkan oleh manajemen } \\
\text { usaha yang masih sangat } \\
\text { sederhana dengan sistem } \\
\text { kekeluargaan. }\end{array}$ \\
\hline Kegiatan & 2. Kegiatan produksi yang \\
\hline
\end{tabular}

\begin{tabular}{|c|c|}
\hline $\begin{array}{l}\text { operasional } \\
\text { produksi yang } \\
\text { dilakukan masih } \\
\text { bersifat home } \\
\text { industry dengan } \\
\text { sistvem } \\
\text { manajemen } \\
\text { sederhana } \\
\text { berdasarkan azas } \\
\text { kekeluargaan, } \\
\text { tidak murni bisnis } \\
\text { (Pure Business). }\end{array}$ & \begin{tabular}{lrr} 
dilakukan & bersifat & industri \\
rumahan & dimana & sistem \\
manajemen & usaha & yang \\
dilakukan & sederhana & dan \\
belum & \multicolumn{2}{c}{ mengadopsi } \\
manajemen & modern.
\end{tabular} \\
\hline $\begin{array}{l}\text { 3. Dalam hal } \\
\text { pemasaran } \\
\text { produknya masih } \\
\text { bergantung pada } \\
\text { pesanan dari agen } \\
\text { ataupun reseller, } \\
\text { tidak langsung } \\
\text { kepada } \\
\text { konsumen. Hal } \\
\text { ini berdampak } \\
\text { pada harga yang } \\
\text { relatif mahal } \\
\text { dipasaran yang } \\
\text { membuat harga } \\
\text { dari produk } \\
\text { kurang bersaing } \\
\text { terhadap produk } \\
\text { lain. }\end{array}$ & $\begin{array}{l}\text { 3. Kegiatan pemasaran masih } \\
\text { sangat sederhana dimana } \\
\text { produk dipasarkan ditoko- } \\
\text { toko dekat pasar. Tidak } \\
\text { adanya promosi membuat } \\
\text { perkembangan usaha ini } \\
\text { berjalan lambat. }\end{array}$ \\
\hline $\begin{array}{l}\text { 4. dalam hal } \\
\text { produksi, proses } \\
\text { produksi masih } \\
\text { sangat lambat hal } \\
\text { ini dikarenakan } \\
\text { jumlah alat yang } \\
\text { tidak memadai } \\
\text { dalam melakukan } \\
\text { produksi barang. }\end{array}$ & $\begin{array}{l}\text { 4. Intensitas, diversifikasi dan } \\
\text { differensiasi produk masih } \\
\text { rendah, hal ini dikarenakan } \\
\text { kurangnya ketersediaan alat } \\
\text { dalam melakukan produksi } \\
\text { barang dan kurangnya } \\
\text { pengetahuan untuk variasi } \\
\text { produk. }\end{array}$ \\
\hline
\end{tabular}

\subsection{Solusi Dan Target Luaran}

Solusi yang diusulkan dalam pelaksanaan yang kegiatan pengabdian masyarakat ini adalah dengan menggunakan media pelatihan dan pendampingan. Kegiatan Pelatihan yang dilaksanakan bertujuan untuk meningkatkan kemampuan dan ketrampilan masyarakat pengrajin mukena dan keset pada beberapa aspek pemasaran dan pembukuan. Pelatihan tersebut juga bertujuan untuk membentuk kesadaran pengrajin mengenai pentingnya pembukuan yang rapi serta pemasaran yang inovatif sehingga dapat memperoleh modal kerja dan bertambah luasnya daerah pemasaran, sehingga menambah omset penjualan.

Untuk mencapai tujuan pelatihan tersebut, maka rancangan pelatihan/penyuluhan yang diharapkan dapat terlaksana adalah sebagai berikut:

1) Pelatihan/penyuluhan di bidang pemasaran. Pelatihan/Penyuluhan di bidang pemasaran adalah Pelatihan Pengemasan Produk mukena 
dan Keset kaki dengan memberi logo dan diberi plastik dan Pelatihan Penggunaan Website Pemasaran Online.

2) Pelatihan/Penyuluhan di bidang pembukuan adalah Pelatihan Pencatatan penerimaan dan pengeluaran ke dalam buku besar, melakukan pencatatan ke dalam jurnal khusus, dan melakukan Perhitungan Harga Pokok Produksi.

3) Pelatihan dan Pendampingan untuk peningkatan kemampuan dalam membordir dan menyulam untuk membuat variasi produk.

Beberapa produk utama dalam kegiatan pengabdian masyarakat ini adalah menghasilkan laporan keuangan sederhana bagi usaha kerajinan keset dan website pemasaran online.

\section{1) Desain Logo Usaha dan Website Pemasaran Online}

Dalam program IbM, diharapkan dapat mengatasi persoalan pemasaran yang selama ini menjadi kendala UKM dalam memasarkan produknya. Selain media promosi diperluas, Program IbM ini didesain untuk membuat media promosi produk secara online yaitu dengan membuatkan website khusus untuk pemasaran produk mukena dan keset, misalnya dengan nama situs: http://www.mukenadankeset.com.

\section{2) Laporan Keuangan Sederhana bagi Mitra I} dan II

Dalam program IbM, diharapkan dapat membekali pengetahuan dan ketrampilan pengrajinmukena dan keset kaki mengenai pembukuan atau laporan keuangan sederhana. Para pengrajin diharapkan mampu membuat pencatan yang rapi mengenai penerimaan dan pengeluaran dalam usaha, mencatat jumlah penjualan ke dalam jurnal khusus dan mencatat perhitungan laporan harga pokok produksi.

3) Pelatihan dan pendampingan untuk peningkatan keahlian

Pelatihan ini di berikan dengan pendampingan oleh instruktur yang memang berkompeten dan ahli dalam membordir, dan dapat memberikan saran dan keahlian lain dalam membuat variasi produk, khususnya pada mukena.

\section{METODE PELAKSANAAN PROGRAM}

\section{a. Persiapan}

Tahap persiapan merupakan tahap awal sebelum pelaksanaan kegiatan. Dalam tahap ini ada beberapa hal yang dilakukan, yaitu:

1) Survey dan persiapan : identifikasi masalah dan analisis kondisi usaha.

2) Koordinasi Internal, dilakukan oleh Tim untuk merencanakan pelaksanaan secara konseptual, operasional, serta job description masingmasing anggota.

3) Penentuan dan rekruitment peserta pelatihan, dalam perekrutan peserta tim pelaksana dibantu oleh pelaku usaha mukena dan keset, untuk mengkoordinir dan mengundang karyawankaryawannya.

4) Persiapan alat dan bahan pelatihan.

5) Persiapan konsumsi, publikasi, lokasi, dokumentasi

\section{b. Pelaksanaan Kegiatan}

Pelaksanaan seluruh kegiatan dilakukan di rumah produksi mukena, sekaligus tempat muntuk pelatihan packing produk. Adapun urutan kegiatan yang dilaksanakan sesuai dengan tujuan kegiatan, yaitu sebagai berikut:

\section{1) Pelatihan dan Pendampingan Bordir dan} Sulam

Salah satu permasalahan yang dihadapi pelaku usaha Mukena dan Keset kaki adalah rendahnya kualitas dari sumber daya manusia hal ini disebabkan oleh rendahnya pengetahuan tentang pembuatan mukena sehingga berpengaruh pada produk yang dihasilkan. Dengan permasalahan tersebut perlu kiranya pelatihan pembuatan mukena dengan menggundang mentor yang sudah ahli dibidang pembuatan mukena, sehingga pelaku usaha dapat mengasilkan produk yang beragam dan tentunya sesuai dengan kebutuhan pasar.

\section{2) Pelatihan Manajemen Dan Pembukuan}

Pelatihan manajemen usaha ini dilakukan dengan memberikan gambaran tentang cara mengelola suatu usaha yang terdiri dari unit unit kecil dibawahnya. Unit- unit kecil ini harus bisa dikelola secara terorganisir/terstruktur untuk menjaga kualitas produk, pelayanan dan yang paling penting adalah kepuasan pelanggan.

Usaha kecil ini juga perlu diarahkan untuk lebih meningkatkan pendapatan dengan mengembangkan usaha dari sisi permodalan. Dengan didapatnya cara meraih modal yang lebih besar diharapkan dapat mengembangkan mukena dan keset kaki.

Perencanaan arah pengembangan usaha ke depan sangat diperlukan pada usaha Mukena dan Keset kai ini, sehingga usaha ini bisa melakukan perluasan usaha dan tentunya akan menambah lapangan pekerjaan. Kegiatan ini juga memberikan gambaran perencanaan dan strategi bagi kelompok sasaran dalam mengembangkan usaha dan target yang akan dicapai. Secara rinci tahap-tahap pelatihan manajemen usaha meliputi: 1) Pelatihan kewirausahaan dengan materi: Pengenalan ciriciri dan watak wirausaha, Strategi menangkap 
peluang besar dan Penyusunan rencana bisnis. Pelatihan manajemen pemasaran meliputi: Strategi penentuan harga, Promosi penjualan, Strategi menghadapi persaingan, Packaging dan labeling.

Langkah-langkah dalam pelaksanaan pelatihan manajemen usaha ini adalah sebagai berikut: 1) Merumuskan materi pelatihan yang relevan, 2) Membuat jadwal pelatihan ,3) Menyiapkan alat dan bahan pelatihan, 4) Pembagian tugas Instruktur, 5) Pelaksanaan pelatihan, dan 6) Melaksanakan evaluasi.

Pelatihan pembukuan diawali dengan Pengenalan sistem pembukuan diperlukan untuk menghitung modal, aset, kondisi keuangan (cash flow), dan keuntungan/ kerugian yang terjadi. Dengan terdatanya kondisi usaha maka akan mudah dalam merancang manajemen, strategi, dan untuk mendapatkan permodalan bagi usaha kecil ini.setelah proses pengenalan langkah selanjutnya adalah pemberian modul dan praktik langsung dalam melakukan penghitungan modal usaha, proses rekapitulasi kas masuk dan keluar dan penyusunan laporan laba usaha.

\section{3) Pelatihan Manajemen Pemasaran Pemasaran Produk}

Pemasaran adalah sesuatu komponen dalam bisnis yang sangat penting, sehingga, setiap usaha disamping harus membuat produk yang berkwalitas dan ekonomis tentunya harus membuat strategi dalam pemasaran. Sehingga produk yang kita hasilkan dikenal oleh konsumen dan juga menjadi barang pilihan dan konsumsi.

Pelatihan ini dilaksanakan dengan memberikan pemahaman terkait mix marketing dalam meningkatkan kemajuan usaha. Yaitu terkait dengan (1). Produk, (2). Harga jual, (3). Promosi, (4). Distribusi, (5). Partisipan, (6). Proses, (7). Lingkungan. Sehingga dengan adanya pemahaman terkait dengan strategi pemasaran ini pelaku usaha dapat melakukan ekspansi usaha dengan parameter bertambahnya outlate usaha dapat dilakukan dengan cepat.

\section{4) Pelatihan pengemasan}

Pelatihan ini dilakukan dengan merancang kemasan yang sesuai dengan produk dan pembuatan logo produk, sehingga dapat memberikan nilai tambah pada produk. Dengan kemasan yang menarik dan tentunya diiringi dengan kualitas produk yang dihasilkan tentunya akan meningkatkan permintaan konsumen.

\section{5) Pelatihan Pembuatan Dan Pengelolaan Wibesite}

Dalam melakukan pemasaran atas produk yang dihasilkan oleh entitas usaha maka perlu dirancang sebuah strategi dalam promosi, sehingga produk yang kita hasilkan dikenal oleh masyarakat luas, sehingga diperlukan media sosial dalam memasarkan produk.

Pelatihan ini dilakukan dengan mendatangkan ahli IT pemasaran, dengan kegiatan yang dilaksanakan adalah pelatihan pembuatan website dan langsung membuat website untuk operasional promosi unit usaha. Dan pelatihan pengelolaan website sehingga web yang dibuat dapat dengan maksimal digunakan untuk promosi, dan juga dapat memberikan informasi yang berhubungan dengan produk secara spesifik. Dengan adanya website dalam usaha ini diharapkan dapat memberikan kemudahan bagi konsumen dalam melakukan permintaan produk, dan dalam transaksi produk tidak perlu tatap muka namun bisa pesan melalui website.

\section{c. Partisipasi Peserta IbM}

Partisipasi mitra program ini diperlukan dalam mensukseskan terlaksananya program IbM ini, antara lain:

1) Memberikan informasi data-data kondisi usaha kecil dan system operasionalnya.

2) Memberi masukan tentang harapan dan target usaha.

3) Mendukung pelaksanaan pelatihan manajemen dan pembukuan serta pemasaran.

4) Mempelajari tentang alur pembukuan keuangan.

5) Mempelajari mix marketing usaha, dan memiliki akun berbagai media social dalam promosi usaha.

\section{d. Pendekatan yang ditawarkan}

Melihat permasalahan yang dihadapi maka langkah-langkah yang dilakuk an untuk mencapai tujuan dan sasaran kegiatan ini maka dilakukan kerjasama yang baik antara dosen pelaksana dengan pelaku usaha serta dalam mendukung pelaksanaan program ini maka akan bekerjasama dengan desainer dalam membantu pembuatan logo dan proses packing produk dan bekerjasama dengan perusahaan IT dalam pelatihan program sehingga kegiatan usaha unit usaha mendapatkan laba pada tingkat yang diharapkan.

\section{e. Evaluasi Pelaksanaan Program}

Proses evaluasi ini dilakukan pada saat sebelum, selama dan setelah pelaksanaan kegiatan. Dengan menggunakan pendekatan community development officer /CDO. Pelatihan dalam pembukuan keuangan dievaluasi dengan penugasan dalam menyiapkan laporan keuangan usahanya. Pelatihan pemasaran 
dilakukan dengan pengelolaan website sebagai sarana dalam melakukan proses promosi.

\section{HASIL YANG DICAPAI}

\section{a. Tahap Persiapan}

Tahap persiapan pelaksanaan Program IbM Tahun 2017 di Sambirejo Kecamatan Percut Sei Tuan dilakukan pada tanggal 13 Mei 2017 untuk membahas tentang persamaan persepsi, instruktur, penetapan jadwal kegiatan, dan penetapan rangkaian kegiatan yang akan dilakukan pada Program IbM Kelompok Usaha Bordir dan Sulam Mukenah dan Jilbab di Desa Sambirejo Kecamatan Percut Sei Tuan. Pertemuan ini dihadiri oleh Tim Pengusul Progam IbM, Ketua Kelompok Usaha/Mitra dan Tenaga Lapangan.

\section{b. Pelaksanaan Kegiatan}

\section{Pendidikan dan Pelatihan Bordir dan Sulam}

Pendidikan dan pelatihan sulam dan bordir ini dilakukan selama tiga tahap. Adapun proses pelaksanaannya, yaitu :

a) Pelatihan Tahap I

Pelatihan dan Pendampingan tahap pertama di pandu oleh instruktur dari Lembaga Kursus Muslimah yaitu, Ibu Eliza Meidar yang memang memiliki keahlian dalam membordir dan menyulam, khususnya sulam bayang untuk mukena, baju, jilbab dll. Pelatihan ini dilakukan terhadap produk bordir mukenah, mengenalkan macammacam produk mukena dengan variasi jenis bordir, gambar bordir, variasi produk dengan bordir dan pengenalam mesin-mesin bordir dan kegunaannya. Diharapkan dengan pelatihan ini kemampuan dan keahlian membordir ibu-ibu kelompok melur makin meningkat, pengetahuan dan wawasan untuk pengembangan produk semakinluas sehingga bisa menyesuaikan dengan permintaan pasar.

b) Pelatihan Tahap II

Setelah mendapatkan pelatihan Membordir, pelatihan dilanjutkan dengan pelatihan menyulam yang di pandu oleh ibu Eliza. Pelatihan menyulam ini dilakukan untuk mengatasi kekurangan alat mesin jahit bordir. Selain itu permintaan pasar terhadap produk mukenah dengan sulam ( khususnya sulam bayang ) dari tahun ke tahun selalu diminati masyarakat dengan variasi bunga sulam dan kain yang berbeda. Selain itu Sulam bayang ini juga sudah banyak di aplikasikan ke produk baju, selendang dan jilbab. Sehingga dengan Praktik bordir dan sulam mukenah dan jilbab ini diharapkan dapat meningkatkan skill anggota-anggota UKM Melur dan Lestari.
Pada awalnya hanya jasa bordir saja kemudian dengan pelatihan ini, skill anggota bertambah dalam bidang menyulam. Produk yang dihasilkan adalah sebagai berikut:

- Mukenah, waktu penyelesaian produk mukenah ini tergantung pada tingkat kerumitan sulaman dan bordiran. Begitu juga dengan harga yang dibanderol untuk satuan mukenah yakni berkisar antara Rp 150.000 - Rp 1.700.000.

- Jilbab, produk ini dijual dengan harga berkisar Rp 40.000 - Rp 50.000.

- Bergo Umroh, produk ini dijual dengan harga berkisar $\mathrm{Rp} 200.000-\mathrm{Rp}$ 250.000.

c) Pelatihan Tahap III

Pada tahap ini hanya dilakukan penyuluhan dan motivasi terhadap pembuatan keset kaki karakter dan sajadah. Proses yang dilakukan pada tahap ini, yaitu memberikan saran untuk menambah karakter kartun untuk keset kaki Memberikan ide untuk membuat ukuran produk yang berbeda, tidak hanya satu ukuran sehingga konsumen dapat mempunyai pilihan utntuk ukuran produk dan harga yang sesuai untuk konsumen. Keset kaki Produk kelompok Melur dan Lestari memiliki ciri khas tersendiri yaitu membuat keset yang memanfaatkan limbah bahan jeans bekas yang di peroleh dari masyarakat sekitar rumah yang dibentuk menyerupai beberapa karakter. Kaset Kaki Karakter ini dijual seharga Rp 50.000 untuk ukuran kecil dan Rp 60.000 untuk ukuran besar. Sajadah, yang ditawarkan UKM Melur dan Lestari dijual seharga Rp 200.000 - Rp 250.000.

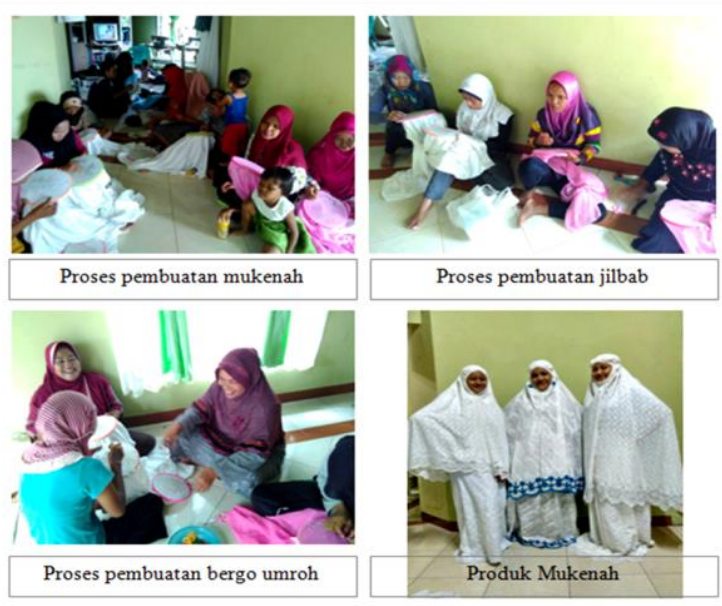

2. Pendidikan dan Pelatihan Manajemen Usaha dan Pembukuan Keuangan

Pendidikan dan pelatihan manajemen usaha dilakukan pada tanggal 17 Juli 2017. Pada pelatihan manajemen usaha adalah penyampaian 
materi tentang pengolahan manajemen usaha yang dilihat dari fungsi-fungsi manajemen usaha yaitu Perencanaan, Pengorganisasian, Pengarahan dan Pengawasan dalam mengelola usaha seperti mengelola sumber daya manusia atau tim kelompok usaha yang dimiliki, bagaimana mengelola sumber daya atau bahanbahan yang digunakan dan SOP dalam berproduksi.

Dalam meningkatkan kelompok usaha yang profesional, tim pelaksana juga membekali kelompok usaha bordir Melur dan Lestari tentang bagaimana mengelola keuangan secara sederhana dengan metode ceramah, diskusi dan praktik langsung dalam membuat laporan keuangan. Diharapkan dengan adanya pelatihan ini, kelompok usaha aksesoris mampu membuat biaya produksi, neraca, laporan rugi laba, dan laporan keuangan sederhana.

\section{Pendidikan dan Pelatihan Pemasaran serta Praktek Pengemasan/Desain Produk (Packaging)}

Pendidikan dan pelatihan pemasaran serta desain produk dilakukan pada 18 Juli 2017. Adapun proses pelaksanaan kegiatannya, yaitu: Penyampaian materi kegiatan tentang bagaimana mendesain kemasan produk Mukena dan Keset Kaki agar terlihat menarik sehingga konsumen ingin membelinya. Hal ini dilakukan dengan memberikan plastik yang bagus dan tas kain untuk mukena. Pengemasan produk juga akan lebih menarik jika didampingi dengan nama dan logo produk yang menarik. Setelah berdiskusi dengan ketua kelompok melur dan Lestari, mereka ingin menamakan produk mukena dan keset kaki mereka dengan nama Zahyan. Karena mereka selalu melakukan penjualan dan pemasaran bersama-sama.

\section{Pelatihan Pembuatan dan Pengelolaan} Website

Pelatihan pembuatan dan pengelolaan Website ini dilakukan pada tanggal 19 Juli 2017. Adapun proses pelaksanaan kegiatannya, yaitu:

a) Penyampaian materi kegiatan tentang bagaimana membuat dan cara mengelola website sebagai salah satu media pemasaran produk.

b) Penyampaian materi tentang pemaparan dan diskusi mengenai pemanfaatan teknologi informasi dan media sosial dalam mengoptimalkan pemasaran produk-produk yang dihasilkan oleh kelompok usaha mitra.

\section{RENCANA TAHAPAN BERIKUTNYA}

Berdasarkan kegiatan yang sudah dilakukan dengan perencanaan sebelumnya, maka rencana tahapan berikutnya, yaitu:
1. Melakukan pendampingan terhadap aktivitas yang dilakukan kelompok usaha Melur dan Lestari untuk kegiatan Bordir dan Sulam atas pendidikan dan pelatihan yang telah diberikan tim pelaksana pada program IbM. Terdapat beberapa aspek yang harus didampingi, yaitu aspek inovasi produk/produksi, aspek pengelolaan keuangan dan aspek pemasaran.

2. Menjadikan kelompok usaha Melur dan Lestari sebagai kelompok usaha binaan Lembaga Pengabdian kepada Masyarakat UNIMED. Sehingga program IbM ini berakhir, proses pendampingan terhadap kelompok uhasa ini tetap berlanjut.

3. Ketua kelompok program IbM mempublikasikan hasil pengabdian kepada masyarakat sebagai pemakalah pada kegiatan Seminar Hasil Pengabdian Masyarakat di Universitas Negeri Medan pada bulan September tahun 2017.

\section{KESIMPULAN DAN SARAN}

\subsection{Kesimpulan}

Berdasarkan dari hasil kegiatan program IbM Kelompok Usaha Bordir dan Keset kaki di Desa Sambirejo Kecamatan Percut Sei Tuan yang sudah dilaksanakan, maka dapat ditarik kesimpulan bahwa Kelompok Meklur dan Lestari (Usaha Bordir dan keset kaki) mampu dalam membuat inovasi produk atau ketrampilan dalam membuat Bordir dan Sulam untuk produk seperti jilbab, mukenah dan keset kaki. Selain itu juga Kelompok Melur dan Lestari mampu mengoperasikan alat mesin jahit dan keahlian menyulam yang telah diberikan sehingga tidak terlalu mengandalkan mesin bordir yang sering rusak dan bisa menambah variasi produk mukena dan jilab dengan teknik sulam bayang, membuat laporan keuangan dan manajemen usaha.

\subsection{Saran}

Saran yang bisa disampaikan dalam kegiatan ini adalah diharapkan adanya program IbM Kelompok Usaha bordir dan Sulam di Desa Sambirejo Kecamatan Percut Sei Tuan dapat dilaksanakan program yang serupa di daerah lainnya yang berpotensi untuk didampingi dan diberikan ketrampilan-ketrampilan baru atau pun program lainnya. Sehingga, akan dapat memberikan manfaat yang lebih luas dalam mendukung program pemerintah untuk mengatasi kemiskinan dan dapat meningkatkan kesejahteraan masyarakat di Indonesia.

\section{DAFTAR PUSTAKA}

Jafar Hafsah. 2004. Upaya Pengembangan Usaha Kecil Dan Menengah (UKM). Infokop Nomor 25 Tahun XX. 
Noer Soetrisno. 2002. Pengembangan UKM, Ekonomi Rakyat Dan Penanggulangan Kemiskinan. Jakarta.

Tarsis Tarmudji. 1996. Prinsip-prinsip Wirausaha. Yogyakarta: Liberty.

Farid. Mochammad. 2014. Kerajinan Keset Dari Kain Perca Di Desa Cerme Kabupaten

Gresik. Artikel IbM. STEI Perbanas Surabaya 